\title{
Paleodietary Analysis of Human Remains from a Hellenistic-Roman Cemetery at Camihöyük, Turkey
}

\author{
Yusuf İzci, ${ }^{1}$ Serdar Kaya, ${ }^{1}$ Onur Erdem, ${ }^{2}$ Cemal Akay, ${ }^{2}$ Cahit Kural, ${ }^{1}$ Buğra Soykut, ${ }^{2}$ \\ Okşan Başoğlu, ${ }^{3}$ Yücel Şenyurt, ${ }^{3}$ Selim Kılıç, ${ }^{4}$ and Çaglar Temiz ${ }^{1}$
}

${ }^{1}$ Department of Neurosurgery, Gülhane Military Medical Academy, Etlik, 06018 Ankara, Turkey
${ }^{2}$ Department of Pharmaceutical Sciences, Gülhane Military Medical Academy, Etlik, 06018 Ankara, Turkey
${ }^{3}$ Department of Archaeology, Gazi University, 06560 Ankara, Turkey
${ }^{4}$ Department of Epidemiology, Gülhane Military Medical Academy, Etlik, 06018 Ankara, Turkey

Correspondence should be addressed to Yusuf İzci; yizci@gata.edu.tr

Received 7 November 2012; Revised 23 January 2013; Accepted 21 February 2013

Academic Editor: Scott M. Fitzpatrick

Copyright (C) 2013 Yusuf İzci et al. This is an open access article distributed under the Creative Commons Attribution License, which permits unrestricted use, distribution, and reproduction in any medium, provided the original work is properly cited.

\begin{abstract}
The presence of copper, zinc, magnesium, iron, lead, molybdenum, manganese and nickel was discovered on 22 human ribs in a Hellenistic-Roman cemetery located in the ancient city of Camihöyük, Turkey. The levels of each element found in the males were higher than those in females, except iron. Copper, magnesium, iron, molybdenum, and nickel levels were measured to be higher in the soil than in the skeletons, whereas the other elements were higher in the human skeletons. Lead was not traced in the soil, but on the skeletons. These individuals had probably been exposed to this element during their lives due to higher consumption of vegetables than meat.
\end{abstract}

\section{Introduction}

Chemical studies on ancient skeletons have a complementary role in learning more about life and human interactions with the environment in a specific archaeological community along with their morphological and geneticoriented counterparts [1]. The concentrations of the bone zinc $(\mathrm{Zn})$, iron $(\mathrm{Fe})$, and copper $(\mathrm{Cu})$ have been considered indicators of high-protein diets, and high concentrations of bone manganese $(\mathrm{Mn})$, barium $(\mathrm{Ba})$, and magnesium $(\mathrm{Mg})$ contents would point to a mainly vegetarian consumption [2-4]. Although the bone $\mathrm{Cu}$ and $\mathrm{Zn}$ levels are associated with paleodiet, the accumulation of some metals such as $\mathrm{Fe}$, molybdenum (Mo), lead $(\mathrm{Pb})$, and nickel $(\mathrm{Ni})$ in the bone tissues may also reflect environmental conditions and pollution $[5,6]$. 95\% of the total $\mathrm{Pb}$ found in the whole body was in bones and teeth which was in the form of chelates. $\mathrm{Pb}$ is known to have toxic effects on many organs, systems, and physiological processes, above all on the development of the central nervous system [7].
The long-term contact with soil, metal belongings in the grave, and the postexcavation exposure $\mathrm{Pb}$ to special challenges and controversies [8]. Diagenesis is defined as a cumulative, physical, biological and chemical process occurring in soil, changing the postmortem chemical and physical structures of bones [1]. Contamination and diagenetic alteration of ancient bones are of great concerns, which, if not properly addressed, may result in serious misinterpretation of data from bone archives [8]. Correction strategies based on burial soil trace element relationship are a promising option for the proper interpretation of the data obtained from bone analysis. Strontium $(\mathrm{Sr})$ and $\mathrm{Zn}$ appear to be the least sensitive elements to diagenesis, while $\mathrm{Fe}, \mathrm{Mn}$, and $\mathrm{Cu}$ are particularly sensitive to diagenetic effects [9]. A major difficulty in understanding the significance of trace element levels in human skeletal remains is the inability to compare populations from different sites directly. In addition, these levels are affected by environmental differences. These are problematic for the comparison of trace element levels in bone samples [10]. 
The purpose of the current study is to obtain an approximate values of certain elements in ancient human bones that are found at Camihöyük archaeological site and to determine the trace element levels in skeletons and soil of the graves. Comparison with the Korean cadaver study was also performed and the levels of $\mathrm{Pb}, \mathrm{Cu}$, and $\mathrm{Zn}$ were comparable with this study [11]. However, the cadaver levels of $\mathrm{Mg}$ and $\mathrm{Ni}$ were not available, thus these elements could not be compared.

\section{Material and Methods}

A total of 31 skeletons from 34 graves were unearthed from Camihöyük archaeological site in 2009 (Figure 1) which are dated to the Hellenistic-Roman period. No skeletons were found in 3 graves. The distribution of grave types is 18 stone cist, 5 cob cist, 4 pot grave, and 7 simple graves. The Stone cist is a stone-lined grave, especially a tomb consisting of a pit lined with stones and often covered with a stone lid. A cob cist is a grave built of clay, sand, straw, water, and earth. Pot grave is a type of ancient grave in which the human body is buried in a pot. Simple grave is another type where the body is buried in the soil. Some burial findings such as bronze coins and earthenware were also found in the graves. One coin, on which the head of Roman Emperor Elagabalus was depicted, is dated to 218-222 AD, because he was the Roman Emperor during this period.

The structures of the graves as well as the objects found in them along with the burial techniques showed that this necropolis belonged to a period between the 2nd and 4th century A.D. Age and gender determination was performed according to the "standards for data collection from human skeletal remains" [12]. Of these 31 skeletons, gender and age of 26 individuals were determined by these techniques. Among them, the rib samples of 22 skeletons, in which the trace element analysis was performed, were collected and stored in dry boxes. The ribs were selected for the trace element analysis, because the rib is more sensitive to diagenetic processes that alter elemental proportions than is the femur [9]. In addition, the femur bones of the skeletons were damaged, and thus not suitable for analysis. A hand auger was used to take surface soil samples $(0-15 \mathrm{~cm}$ depth) from the excavation site of the graves. The soil samples were collected just above the graves and were placed in plastic bags.

A Perkin Elmer AS-800 atomic absorption spectrometer (FAAS) equipped with HGA graphite furnace (GFAAS) was used for analysis. For flame measurements, a $10 \mathrm{~cm}$ long slot burner head, a lamp, and an air-acetylene flame were used. For graphite furnace measurements, argon (99.98\%, Oksan, Ankara) was used as a carrier gas. The operating parameters for the investigated elements were set as recommended by the manufacturer (Table 1). Pyrolytic-coated graphite tubes (Perkin Elmer part no. BO 504033) with a platform were used. Samples were injected into the graphite furnace using a Perkin Elmer AS-800 autosampler. Milestone 1200 Mega closed vessel microwave digestion system (maximum pressure $1450 \mathrm{psi}$, maximum temperature $300^{\circ} \mathrm{C}$ ) was used. Teflon reaction vessels were used in all the digestion procedures.

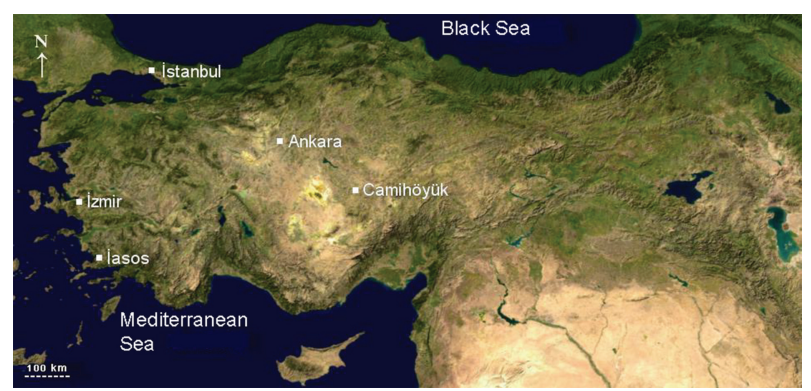

Figure 1: Camihöyük is located in Central Anatolia.

The reaction vessels were cleaned using $5 \mathrm{~mL}$ of concentrated nitric acid before each digestion. All reagents used in the analysis were of analytical grade. All aqueous solutions were prepared with deionized water obtained by using ultra pure water system (Aqua Nova Hepta Distillated, resistivity $0.34 \mathrm{M} \Omega$-cm, Sweden). $\mathrm{HNO}_{3}(65 \% \mathrm{~m} / \mathrm{m})$ and $\mathrm{H}_{2} \mathrm{O}_{2}(35 \%$ $\mathrm{m} / \mathrm{m}$ ) from Merck supra-pure grade were used for digestion of the samples and dilution. Plastic bottles, autosampler cups, teflon vessels, and vials were used for collecting samples, and glassware were cleaned by soaking in $\mathrm{HNO}_{3}(10 \% \mathrm{v} / \mathrm{v})$ for a period of $24 \mathrm{~h}$, rinsing four times in ultrapure water and drying in an oven at $40^{\circ} \mathrm{C}$. All solutions were stored in high density polypropylene bottles. Autosampler washing solution containing $\mathrm{HNO}_{3}(0.2 \% \mathrm{v} / \mathrm{v})$ was used to avoid clogging of the autosampler sampling capillary tip and to improve dispersion of sample solution onto the graphite tube. Stock standard solutions of analytes $(1 \mathrm{~g} / \mathrm{L}$ each) obtained from Merck were also used. Working standard solutions were freshly prepared by diluting the stock standard solutions to the desired calibration ranges in $0.2 \% \mathrm{HNO}_{3}$ as diluents. Microwave digestion procedure was applied for bone and soil samples. $0.15-0.25 \mathrm{~g}$ of each bone sample was digested with $3 \mathrm{~mL}$ of $\mathrm{HNO}_{3}(65 \%)$ and $0.5 \mathrm{~mL}$ of $\mathrm{H}_{2} \mathrm{O}_{2}(30 \%)$ in a microwave digestion system and diluted to $5 \mathrm{~mL}$ with deionized water. A blank digest was carried out in the same way. $0.18 \mathrm{~g}$ of soil sample was digested with $4 \mathrm{~mL}$ of $\mathrm{HF}$ (40\%) and $1 \mathrm{~mL}$ of $\mathrm{HCIO}_{4}(70 \%)$ in a microwave digestion system and diluted to $5 \mathrm{~mL}$ with deionized water. All sample solutions were clear. Digestion conditions for the microwave system were applied for bone samples as $2 \mathrm{~min}$ for $250 \mathrm{~W}$, $2 \mathrm{~min}$ for $0 \mathrm{~W}, 3 \mathrm{~min}$ for $250 \mathrm{~W}, 4 \mathrm{~min}$ for $400 \mathrm{~W}$, and $5 \mathrm{~min}$ for $650 \mathrm{~W}$, vent: $8 \mathrm{~min}$ and $5 \mathrm{~min}$ for $250 \mathrm{~W}, 5 \mathrm{~min}$ for $400 \mathrm{~W}$, $10 \mathrm{~min}$ for $500 \mathrm{~W}, 3 \mathrm{~min}$ for $250 \mathrm{~W}$, vent: $10 \mathrm{~min}$ for soil, respectively.

Detection limit is defined as the concentration corresponding to three times the standard deviation of 10 blanks. Detection limit values of elements as milligram per liter in flame AAS were found to be 0.006 for $\mathrm{Zn}, 0.007$ for $\mathrm{Cu}$, and $\mathrm{Fe}$ and 0.015 for $\mathrm{Mg}$. $\mathrm{Pb}$, molybdenum, manganese, and nickel were determined using graphite furnace AAS. During analyses, internal argon flow rate through the graphite tube was $250 \mathrm{~mL} / \mathrm{min}$, where gas flow was interrupted during atomization. Sample volume, ramp, and hold times for the drying, ashing, atomization, and cleaning temperatures were optimized before analysis to obtain the maximum absorbance 
TABLE 1: Instrumental conditions of investigated analytes.

\begin{tabular}{|c|c|c|c|c|c|}
\hline \multicolumn{6}{|c|}{ FAAS } \\
\hline & Acetylene (L/min) & Air (L/min) & Wavelength (nm) & Slit width $(\mathrm{nm})$ & Lamp current (mA) \\
\hline \multicolumn{6}{|l|}{ Element } \\
\hline $\mathrm{Fe}$ & 2.0 & 17.0 & 248.3 & 0.2 & 30 \\
\hline $\mathrm{Zn}$ & 2.0 & 17.0 & 213.9 & 0.7 & 15 \\
\hline $\mathrm{Cu}$ & 2.0 & 17.0 & 324.8 & 0.7 & 15 \\
\hline $\mathrm{Mg}$ & 2.0 & 17.0 & 285.0 & 0.7 & 6 \\
\hline Instrumental conditions & $\mathrm{Pb}$ & Mo & $\mathrm{Mn}$ & $\mathrm{Ni}$ & \\
\hline Wavelength (nm) & 283.3 & 313.3 & 279.5 & 232.0 & \\
\hline Slit width (nm) & 0.7 & 0.7 & 0.2 & 0.7 & \\
\hline Lamp current (mA) & 30 & 30 & 20 & 25 & \\
\hline Argon flow (mL/min) & 250 & 250 & 250 & 250 & \\
\hline Sample volume & 20 & 20 & 20 & 20 & \\
\hline \multicolumn{6}{|c|}{ Heating program temperature } \\
\hline Drying 1 & $110(1,30)$ & $110(1,30)$ & $110(1,30)$ & $110(1,30)$ & \\
\hline Drying 2 & $130(15,15)$ & $130(15,30)$ & $130(15,30)$ & $130(15,30)$ & \\
\hline Ashing & $750(10,15)$ & $1500(10,20)$ & $1300(10,20)$ & $1000(10,20)$ & \\
\hline Atomization & $1600(0,3)$ & $2450(0,7)$ & $1900(0,3)$ & $2300(0,5)$ & \\
\hline Cleaning & $2450(1,3)$ & $2500(1,5)$ & $2600(1,3)$ & $2600(1,3)$ & \\
\hline
\end{tabular}

and the minimum background. Each graphite furnace atomic absorption spectroscopic analysis calls for $20 \mu \mathrm{L}$ of solution, $5-10 \mu \mathrm{L}$ of the matrix modifier was added if necessary. The signals were measured as peak area. The absolute sensitivity is defined by the mass of an element, which gives a peak absorbance of $0.004 ; 20 \mathrm{pg} / \mathrm{mL}$ for $\mathrm{Pb}, 2 \mathrm{pg} / \mathrm{mL}$ for $\mathrm{Mo}$, $3 \mathrm{pg} / \mathrm{mL}$ for $\mathrm{Mn}$, and $20 \mathrm{pg} / \mathrm{mL}$ for $\mathrm{Ni}$, were found.

In this study, microwave digestion system was preferred because of its high accuracy of time and recovery values. The recovery values were nearly quantitative for microwave digestion method. The accuracy of the method was evaluated by means of trace element determination in standard reference material. In this study, the accuracy rate of the metals is above $96 \%$.

Groups were compared with the Mann-Whitney $U$ test (SPSS for Windows, 13.0). The results were not compared for age groups, because there were only 3 children skeletons and the rest were adults. The results of 8 elements in 22 skeletons were also compared with the soil element analysis. The bone/soil ratio was also calculated for each element. $P<$ 0.05 was considered to be statistically significant.

\section{Results}

Table 2 shows concentrations of metals, the complete set of bones employed in the study, with the individuals from which samples were obtained, the estimated age according to archaeologists and the burial site, with the analytical results for the metals studied in each of the samples.

The results of elemental analysis of the Camihöyük skeletal series and soil are shown in Tables 3 and 4. The age groups are arranged into 2 groups: children ( $0-17$ years) and adults (18-34 years). The range of $\mathrm{Cu}$ levels in the bone samples is between 0 and $4.81 \mu \mathrm{g} / \mathrm{g}$ with the average of $1.89 \mu \mathrm{g} / \mathrm{g}$. Male group had the highest mean of $\mathrm{Cu}$ level $(1.20 \mu \mathrm{g} / \mathrm{g})$ and female group had the lowest level $(0.47 \mu \mathrm{g} / \mathrm{g})$. Although some differences were found in terms of gender, this effect was not statistically significant $(P>0.05)$. The $\mathrm{Cu}$ level in the soil was $11.34 \mu \mathrm{g} / \mathrm{g}$ and the ratio of bone/soil for $\mathrm{Cu}$ was 0.17 .

The range of $\mathrm{Mg}$ levels in the bone samples was between $46.91 \mu \mathrm{g} / \mathrm{g}$ and $63.59 \mu \mathrm{g} / \mathrm{g}$ with the average of $56.58 \mu \mathrm{g} / \mathrm{g}$. The male group had higher mean of $\mathrm{Mg}$ value $(57.34 \mu \mathrm{g} / \mathrm{g})$ than the female group where the mean $\mathrm{Mg}$ level was $54.02 \mu \mathrm{g} / \mathrm{g}$. There was no significant difference of $\mathrm{Mg}$ among the two genders $(P>0.05)$. The level of $\mathrm{Mg}$ in the soil was $58.68 \mu \mathrm{g} / \mathrm{g}$ and the ratio of bone/soil for $\mathrm{Mg}$ was 0.96 .

The range of $\mathrm{Zn}$ levels in the bone samples was between $47.59 \mu \mathrm{g} / \mathrm{g}$ and $166.54 \mu \mathrm{g} / \mathrm{g}$ with the average of $96.38 \mu \mathrm{g} / \mathrm{g}$. The lower mean $\mathrm{Zn}$ value refers to female group $(76.56 \mu \mathrm{g} / \mathrm{g})$, whereas male group had a higher value $(102.21 \mu \mathrm{g} / \mathrm{g})$. There were no significant differences between female and male groups $(P>0.05)$. The $\mathrm{Zn}$ level in the soil was $32.32 \mu \mathrm{g} / \mathrm{g}$ and the ratio of bone/soil for $\mathrm{Zn}$ was 2.98. The range of Fe levels in the bone samples was between $73.37 \mu \mathrm{g} / \mathrm{g}$ and $554.70 \mu \mathrm{g} / \mathrm{g}$ with the average of $244.83 \mu \mathrm{g} / \mathrm{g}$. The higher mean Fe value refers to female group $(295.26 \mu \mathrm{g} / \mathrm{g})$. The mean Fe value in male group was $230.00 \mu \mathrm{g} / \mathrm{g}$. But, there was no significant difference between male and female groups $(P>0.05)$. The Fe level in the soil was $1278 \mu \mathrm{g} / \mathrm{g}$ and the ratio of bone/soil for $\mathrm{Fe}$ was 0.19 . The range of $\mathrm{Pb}$ levels in the bone samples ranged between $0.76 \mu \mathrm{g} / \mathrm{g}$ and $9.41 \mu \mathrm{g} / \mathrm{g}$ with the average of $3.26 \mu \mathrm{g} / \mathrm{g}$. The male group had the higher mean $\mathrm{Pb}$ value $(3.42 \mu \mathrm{g} / \mathrm{g})$ and the female group had the lower $\mathrm{Pb}$ level $(2.71 \mu \mathrm{g} / \mathrm{g})$. There was no significant difference between $\mathrm{Pb}$ values and gender $(P>0.05)$. But, no $\mathrm{Pb}$ was detected in 
TABLE 2: Concentrations in $\mu \mathrm{g} / \mathrm{g}$ of the metals in human bones. (A: adult, Ch: child, M: male, F: female).

\begin{tabular}{|c|c|c|c|c|c|c|c|c|c|c|}
\hline Individual & Age group & Gender & $\mathrm{Cu}(\mu \mathrm{g} / \mathrm{g})$ & $\mathrm{Mg}(\mu \mathrm{g} / \mathrm{g})$ & $\mathrm{Zn}(\mu \mathrm{g} / \mathrm{g})$ & $\mathrm{Fe}(\mu \mathrm{g} / \mathrm{g})$ & $\mathrm{Pb}(\mu \mathrm{g} / \mathrm{g})$ & Mo $(\mu \mathrm{g} / \mathrm{g})$ & $\mathrm{Mn}(\mu \mathrm{g} / \mathrm{g})$ & $\mathrm{Ni}(\mu \mathrm{g} / \mathrm{g})$ \\
\hline 1 & A & M & 0.00 & 56.35 & 107.23 & 106.40 & 3.20 & 3.44 & 2.23 & 3.26 \\
\hline 2 & $\mathrm{Ch}$ & $\mathrm{F}$ & 0.00 & 60.74 & 123.32 & 165.50 & 3.71 & 2.54 & 3.76 & 2.78 \\
\hline 3 & A & M & 2.70 & 63.59 & 163.92 & 290.70 & 3.27 & 0.45 & 1.40 & 3.58 \\
\hline 4 & A & M & 4.81 & 59.55 & 151.80 & 390.50 & 2.81 & 1.53 & 0.15 & 4.45 \\
\hline 5 & A & $\mathrm{F}$ & 1.57 & 50.08 & 83.51 & 554.70 & 3.51 & 0.49 & 0.58 & 3.76 \\
\hline 6 & A & M & 0.00 & 49.27 & 67.26 & 184.20 & 2.97 & 0.22 & 1.98 & 2.35 \\
\hline 7 & A & M & 0.00 & 61.60 & 63.67 & 287.00 & 3.44 & 0.00 & 3.54 & 3.14 \\
\hline 8 & A & M & 0.00 & 57.96 & 70.64 & 144.20 & 2.17 & 0.31 & 3.68 & 2.53 \\
\hline 9 & A & M & 4.11 & 51.37 & 122.13 & 279.60 & 3.93 & 4.34 & 1.26 & 4.62 \\
\hline 10 & A & M & 0.99 & 59.61 & 107.40 & 417.70 & 4.29 & 0.77 & 3.58 & 4.30 \\
\hline 11 & A & M & 1.66 & 50.69 & 92.44 & 390.40 & 5.05 & 1.44 & 0.80 & 3.60 \\
\hline 12 & A & M & 0.00 & 58.14 & 166.54 & 130.00 & 2.37 & 4.99 & 4.27 & 2.87 \\
\hline 13 & A & $\mathrm{F}$ & 0.00 & 55.89 & 69.21 & 194.40 & 2.15 & 1.44 & 1.84 & 2.82 \\
\hline 14 & A & M & 0.00 & 61.93 & 74.70 & 234.60 & 9.41 & 0.17 & 2.59 & 2.70 \\
\hline 15 & A & M & 0.00 & 56.47 & 59.15 & 292.50 & 2.40 & 2.02 & 3.40 & 3.30 \\
\hline 16 & A & M & 0.38 & 57.62 & 56.32 & 420.20 & 5.01 & 0.23 & 2.65 & 3.65 \\
\hline 17 & A & M & 2.20 & 48.73 & 108.15 & 187.80 & 3.02 & 0.00 & 0.69 & 2.64 \\
\hline 18 & A & M & 0.00 & 61.03 & 86.54 & 73.37 & 0.76 & 0.92 & 3.08 & 2.21 \\
\hline 19 & A & $\mathrm{F}$ & 0.80 & 46.91 & 47.59 & 269.20 & 1.77 & 0.00 & 0.49 & 2.93 \\
\hline 20 & $\mathrm{Ch}$ & $\mathrm{F}$ & 0.82 & 62.12 & 102.10 & 155.90 & 1.07 & 2.75 & 1.34 & 4.68 \\
\hline 21 & $\mathrm{Ch}$ & M & 0.63 & 60.92 & 84.99 & 101.00 & 2.75 & 22.45 & 4.35 & 1.80 \\
\hline 22 & A & M & 2.04 & 54.27 & 111.70 & 116.40 & 2.71 & 20.14 & 3.00 & 2.06 \\
\hline
\end{tabular}

TABLE 3: Concentrations in $\mu \mathrm{g} / \mathrm{g}$ of the metals in human bones and soil according to gender.

\begin{tabular}{|c|c|c|c|c|c|c|c|c|}
\hline Gender & $\begin{array}{c}\mathrm{Cu} \\
(\text { mean } \pm \text { S.D. })\end{array}$ & $\begin{array}{c}\mathrm{Mg} \\
\text { (mean } \pm \text { S.D.) }\end{array}$ & $\begin{array}{c}\mathrm{Zn} \\
\text { (mean } \pm \text { S.D.) }\end{array}$ & $\begin{array}{c}\mathrm{Fe} \\
(\text { mean } \pm \text { S.D. })\end{array}$ & $\begin{array}{c}\mathrm{Pb} \\
(\text { mean } \pm \text { S.D. })\end{array}$ & $\begin{array}{c}\text { Mo } \\
(\text { mean } \pm \text { S.D. })\end{array}$ & $\begin{array}{c}\mathrm{Mn} \\
(\text { mean } \pm \text { S.D. })\end{array}$ & $\begin{array}{c}\mathrm{Ni} \\
\text { (mean } \pm \text { S.D.) }\end{array}$ \\
\hline $\begin{array}{l}\text { Male } \\
(n=17)\end{array}$ & $1.20 \pm 1.52$ & $57.34 \pm 4.80$ & $102.21 \pm 33.71$ & $230.00 \pm 119.48$ & $3.43 \pm 1.92$ & $3.77 \pm 6.79$ & $2.39 \pm 1.29$ & $3.20 \pm 0.92$ \\
\hline $\begin{array}{l}\text { Female } \\
(n=5)\end{array}$ & $0.47 \pm 0.70$ & $54.02 \pm 5.50$ & $76.56 \pm 29.29$ & $295.26 \pm 154.16$ & $2.71 \pm 0.86$ & $1.30 \pm 1.05$ & $2.01 \pm 1.53$ & $3.12 \pm 0.41$ \\
\hline$P$ value & 0.324 & 0.147 & 0.127 & 0.290 & 0.411 & 0.814 & 0.557 & 0.845 \\
\hline Soil & 11.34 & 58.68 & 32.32 & 1278 & 0 & 9.06 & 1.59 & 7.07 \\
\hline
\end{tabular}

the soil of excavation site. The range of Mo levels in the bone samples ranged between $0 \mu \mathrm{g} / \mathrm{g}$ and $22.45 \mu \mathrm{g} / \mathrm{g}$ with the average of $3.72 \mu \mathrm{g} / \mathrm{g}$. The higher mean Mo value refers to male group $(3.77 \mu \mathrm{g} / \mathrm{g})$. The mean Mo value in female group was $1.30 \mu \mathrm{g} / \mathrm{g}$. But there was no significant difference between male and female groups $(P>0.05)$. The level of Mo in the soil was $9.06 \mu \mathrm{g} / \mathrm{g}$ and the ratio of bone/soil for Mo was 0.41 . The range of Mn levels in the bone samples was between $0.15 \mu \mathrm{g} / \mathrm{g}$ and $4.35 \mu \mathrm{g} / \mathrm{g}$ with the average of $2.30 \mu \mathrm{g} / \mathrm{g}$. The mean $\mathrm{Mn}$ values were $2.39 \mu \mathrm{g} / \mathrm{g}$ in male group and 2.01 in female group, respectively. There was no significant difference between male and female groups $(P>0.05)$. The Mn level in the soil was $1.59 \mu \mathrm{g} / \mathrm{g}$ and the ratio of bone/soil for $\mathrm{Mn}$ was 1.45 . In a similar way, the mean $\mathrm{Ni}$ values of the each gender group were notably close to each other. The mean Ni value of the skeletons was $3.18 \mu \mathrm{g} / \mathrm{g}$ (ranged between $1.80 \mu \mathrm{g} / \mathrm{g}$ and $4.68 \mu \mathrm{g} / \mathrm{g}$ ). The female group had the lower mean $\mathrm{Ni}$ value $(3.12 \mu \mathrm{g} / \mathrm{g})$. The mean Ni value for male group was $3.20 \mu \mathrm{g} / \mathrm{g}$. However, no statistically significant result had been found based on $\mathrm{Ni}$ levels related with gender groups $(P>0.05)$. The Ni level in the soil was $7.07 \mu \mathrm{g} / \mathrm{g}$ and the ratio of bone/soil for $\mathrm{Ni}$ was 0.45 .

\section{Discussion}

Bone tissue has been widely used to study accumulated exposure to metals, since it is the main mineral component of the human body [7]. This study has been performed on skeletal material and soil samples from the necropolis of Camihöyük archaeological site. The site is located in Central Anatolia, $17 \mathrm{~km}$ northwest of Avanos, Nevşehir. The construction of the graves, the burial techniques, and burial gifts indicated that this is a late-Roman period cemetery. The chemical analysis of the bones obtained from the site showed that vegetal sources constituted an important part of the diet. High $\mathrm{Cu}, \mathrm{Fe}$, and $\mathrm{Mn}$ levels may indicate highprotein consumption; however, this is not reliable because $\mathrm{Fe}, \mathrm{Mn}$, and $\mathrm{Cu}$ are sensitive to diagenesis. The mean $\mathrm{Mn}$ 
TABLE 4: Concentrations in $\mu \mathrm{g} / \mathrm{g}$ of the metals in human bones and soil according to age groups.

\begin{tabular}{|c|c|c|c|c|c|c|c|c|}
\hline Age group & $\begin{array}{c}\mathrm{Cu} \\
(\text { mean } \pm \text { S.D. })\end{array}$ & $\begin{array}{c}\mathrm{Mg} \\
\text { (mean } \pm \text { S.D.) }\end{array}$ & $\begin{array}{c}\mathrm{Zn} \\
(\text { mean } \pm \text { S.D. })\end{array}$ & $\begin{array}{c}\mathrm{Fe} \\
(\mathrm{mean} \pm \text { S.D. })\end{array}$ & $\begin{array}{c}\mathrm{Pb} \\
(\text { mean } \pm \text { S.D. })\end{array}$ & $\begin{array}{c}\text { Mo } \\
\text { (mean } \pm \text { S.D. })\end{array}$ & $\begin{array}{c}\mathrm{Mn} \\
\text { (mean } \pm \text { S.D.) }\end{array}$ & $\begin{array}{c}\mathrm{Ni} \\
(\text { mean } \pm \text { S.D. })\end{array}$ \\
\hline $\begin{array}{l}\text { Adult } \\
(n=19)\end{array}$ & $1.10 \pm 1.50$ & $56.01 \pm 51.36$ & $98.78 \pm 35.18$ & $247.85 \pm 124.80$ & $3.32 \pm 1.76$ & $2.38 \pm 4.55$ & $2.23 \pm 1.32$ & $3.15 \pm 0.74$ \\
\hline $\begin{array}{l}\text { Children } \\
(n=3)\end{array}$ & $0.61 \pm 0.22$ & $60.22 \pm 2.33$ & $81.14 \pm 23.13$ & $225.70 \pm 170.66$ & $2.94 \pm 1.98$ & $8.48 \pm 12.17$ & $2.78 \pm 1.51$ & $3.38 \pm 1.46$ \\
\hline$P$ value & 0.197 & 0.802 & 0.363 & 0.667 & 0.738 & 0.314 & 0.473 & 0.599 \\
\hline Soil & 11.34 & 58.68 & 32.32 & 1278 & 0 & 9.06 & 1.59 & 7.07 \\
\hline
\end{tabular}

concentration in the bones was higher than that in the soil, whereas the elements were lower.

Many studies about toxic metal and trace element analysis have been carried out to reveal the paleodiet and life conditions of ancient populations $[7,13,14] . \mathrm{Pb}, \mathrm{Zn}, \mathrm{Cu}, \mathrm{Ni}$, and $\mathrm{Fe}$ are accumulated in bones in different degrees and for different reasons. $\mathrm{Zn}$ is a bone seeking element under strong physiological condition [15]. Fe is primarily sourced from soil burial contamination [16]. $\mathrm{Cu}, \mathrm{Ni}$, and $\mathrm{Zn}$ are essential trace elements, and $\mathrm{Ni}$ is also a potential drill bit contamination tracer [17]. So, it might be Ni contamination if there was a high Ni level in the bones.

The concentration of $\mathrm{Pb}$ in bones in different periods in history has been reported by numerous authors $[18,19]$, more than $90 \%$ of the bodily load of Pb being found in the skeleton, where replacement is slow [20]. This period varies depending on the part of the bone considered, ranging between 16 and 27 years. The concentration of $\mathrm{Pb}$ in bones thus, reflects long-term exposure [14]. $\mathrm{Pb}$, which is only present in human body as a contaminant, is a biogeochemical analog to calcium though it has no known biological role. It is one of the earliest metals discovered by the human race and is in use since 3000 B.C. The ancient Romans used $\mathrm{Pb}$ for making water pipes, coins and lining baths. The oldest known object that contains $\mathrm{Pb}$ made by humankind is a small statue found in Turkey, dated 6,500 B.C. [21]. At Camihöyük excavation site, no object made with $\mathrm{Pb}$ was found. Additionally $\mathrm{Pb}$ was also not detected in grave soil either. The high $\mathrm{Pb}$ level in the bone samples without significant presence in the soil showed that this population is exposed to $\mathrm{Pb}$ during their life. Probably, the $\mathrm{Pb}$ exposure to this people occurred by water pipes and coins which were used during their life.

$\mathrm{Ni}$ is a trace element, required in minute quantities by the human body. It is found widely in the environment and also almost in all tissues of the body. Though present in trace quantities, Ni can accumulate in kidneys, bones, and thyroid gland and cause toxicity or carcinogenic effect. It can enter in the body by eating, drinking, or breathing. Children, and to a lesser extent, adults can also be exposed by ingesting soils. Plants are the main dietary source of $\mathrm{Ni}$. Animal-originated foods are a poor source of $\mathrm{Ni}$, while drinking water contributes to Ni considerably [22]. Alloys of nickel are known and used for thousands of years before its identification as a metallic element. There is a reliable evidence of prehistoric man-made use of iron-nickel alloys of meteoric origin [23]. The earliest authenticated artifact from such a source is believed to be a portion of a dagger found at
Ur of the Chaldees (c. 3100 B.C.), shown to contain $10.9 \% \mathrm{Ni}$ [24]. The first man-made alloy containing nickel is a bronze reamer containing $2.73 \%$ nickel found in the plain of Antioch believed to date to 3500-3100 B.C [25]. The earliest coppernickel alloy objects which are known to have survived to the present day are coins minted in Bactria, an ancient kingdom situated north of present-day Afghanistan. These coins were dated to c.a. 200 BC [26]. Nickel is first isolated in 1751 by Cronstedt [27]. In the soil of excavations, the Ni level was found $7.07 \mu \mathrm{g} / \mathrm{g}$, which is very high when compared to $\mathrm{Ni}$ levels in human bones. The mean Ni level in the skeletons was $3.18 \mu \mathrm{g} / \mathrm{g}$ which shows the contamination from the soil.

$\mathrm{Cu}$ is a very important element for health and body functions. To begin with, $\mathrm{Cu}$ is a major component of the oxygen carrying part of blood cells. $\mathrm{Cu}$, along with vitamin $\mathrm{C}$, is important for keeping the elastic and flexible structure blood vessels and skin. It is also required by the brain to form chemicals that keep us awake and alert [28]. In our study, the mean $\mathrm{Cu}$ level was $1.89 \mu \mathrm{g} / \mathrm{g}$ in the bones. There were some differences in terms of gender, but these differences are not statistically significant. The $\mathrm{Cu}$ level in the soil was $11.34 \mu \mathrm{g} / \mathrm{g}$ and the $\mathrm{Cu}$ ratio of bone/soil was 0.17 . The $\mathrm{Cu}$ concentration in the soil was very high when compared to the bones. $\mathrm{Cu}$ is particularly sensitive to diagenetic effects of the soil; therefore, it is difficult to interpret the $\mathrm{Cu}$ concentration in the bones.

Mo is an essential element for humans, with the highest concentrations found in the liver, kidneys, adrenal gland, and bones. It is a component of a number of enzymes involved in the metabolism of various amino acids. Foods that are rich in Mo include legume, cereals, and leafy vegetables. Mo is absorbed and excreted rapidly, but the rate of excretion is less than the rate of absorption, so there is some accumulation of Mo in the body (especially bones), and the amount stored increases with administered dose. Bone retains Mo longer than any other tissue [29]. The mean Mo level was $3.72 \mu \mathrm{g} / \mathrm{g}$ in the bones, and there was no statistical difference between male and female groups. The Mo level in the soil was $9.06 \mu \mathrm{g} / \mathrm{g}$ and the ratio of bone/soil for Mo is 0.41 . The Mo concentration in the bones was probably affected by the soil.

$\mathrm{Zn}$ is ubiquitous in body tissues and serves many essential functions in numerous protein and enzyme systems [18]. Gilbert [30] suggested the use of $\mathrm{Zn}$ as a further aid to dietary reconstructions. A firm relationship between dietary and skeletal concentrations has been demonstrated [31]. Analysis of bone $\mathrm{Zn}$ levels of animals raised via controlled diets has shown $\mathrm{Zn}$ levels to be consistently around $100 \mu \mathrm{g} / \mathrm{g}$, 
in association with herbivores while reaching $250 \mu \mathrm{g} / \mathrm{g}$ in carnivores [32]. $\mathrm{Zn}$ levels in bone appear to be stable and are independent of disease except for instances of severe calcium deprivation [33]. Zn concentrations do not fluctuate by age among adults [34]. In our study, the mean $\mathrm{Zn}$ concentration was $96.38 \mu \mathrm{g} / \mathrm{g}$, and the male group had higher $\mathrm{Zn}$ concentration than the female group, but this difference was not statistically significant. The Zn level in the soil was $32.32 \mu \mathrm{g} / \mathrm{g}$ and the ratio of bone/soil for $\mathrm{Zn}$ was 2.98 . Interestingly, the $\mathrm{Zn}$ level in the soil was very low as compared to the bones. However, the mean $\mathrm{Zn}$ level was not higher than $100 \mu \mathrm{g} / \mathrm{g}$. Therefore, it is concluded that the people of Camihöyük consumed more vegetables than meat.

$\mathrm{Mn}$ is a naturally occurring element and present abundantly in the environment. While essential to human health, overexposure to $\mathrm{Mn}$ is associated with devastating neurologic impairment clinically known as "manganism," a motor syndrome similar to, but partially distinguishable from, idiopathic Parkinson's disease. It should be pointed out that nearly $40 \%$ of $\mathrm{Mn}$ accumulates in bone [35]. Recently, a rapid development in X-ray fluorescence spectroscopy and neutron-based spectroscopy has made it possible to detect low levels of a variety of metals, including $\mathrm{Pb}$, in bones [36]. In our study, bone Mn concentration was higher than the soil. This shows that Camihöyük population consumed vegetables more than meat. Diagenesis may also occur in these bones, but the diagenetic effect of the soil was minimal.

Fe is pervasive, and particularly rich sources of dietary Fe include red meat, beans, poultry, fish, and leaf vegetables. When Fe uptake occurs in the bone, the Fe replaces calcium in the inorganic compartment of the bone, probably in the form of ferric phosphate [37]. We detected higher Fe levels in soil than in the bones. This is secondary to diagenesis, and the Fe came from the soil. We did not find any burial gifts made of iron in the cemetery. The possible source of $\mathrm{Fe}$ is unclear.

$\mathrm{Mg}$ is the fourth most abundant mineral in the body and is essential for health [38]. Approximately $50 \%$ of total body $\mathrm{Mg}$ is found in bones. Green vegetables such as spinach are good sources of $\mathrm{Mg}$, because the center of the chlorophyll molecule (which gives the green color to vegetables) contains $\mathrm{Mg}$ [39]. In our study, the $\mathrm{Mg}$ concentration in the soil is approximately equivalent to those of the bones. $\mathrm{Mg}$ and $\mathrm{Mn}$ were chosen in this study because they occur in large amounts in vegetables. However, diagenetic effect of soil on the bones could not be determined.

Yoo et al. [11] studied heavy metals in 150 Korean autopsy cadavers and measured the mean level in bone for each metal and each gender. The bone level of Mo in human cadavers was $0.09 \mu \mathrm{g} / \mathrm{g}$ in males and $0.10 \mu \mathrm{g} / \mathrm{g}$ in females. For $\mathrm{Cu}$, the concentration was $0.51 \mu \mathrm{g} / \mathrm{g}$ in male and $0.62 \mu \mathrm{g} / \mathrm{g}$ in female cadavers. For Fe, the concentration was $70 \mu \mathrm{g} / \mathrm{g}$ in male cadavers and $41 \mu \mathrm{g} / \mathrm{g}$ in female cadavers. For Mn, the concentration was $0.07 \mu \mathrm{g} / \mathrm{g}$ in each gender. For Ni, the concentration was $0.08 \mu \mathrm{g} / \mathrm{g}$ in male and $0.09 \mu \mathrm{g} / \mathrm{g}$ in female cadavers. For $\mathrm{Pb}$, the concentration was $1.6 \mu \mathrm{g} / \mathrm{g}$ in male and $1.4 \mu \mathrm{g} / \mathrm{g}$ in female cadavers. For $\mathrm{Zn}$, the concentration was $43 \mu \mathrm{g} / \mathrm{g}$ in males and $47 \mu \mathrm{g} / \mathrm{g}$ in female cadavers. In our study, the mean bone levels of $\mathrm{Mo}, \mathrm{Cu}, \mathrm{Fe}, \mathrm{Mn}, \mathrm{Pb}, \mathrm{Ni}$, and $\mathrm{Zn}$ were higher than the results of Yoo et al. The possible cause for these high levels is diagenesis. Therefore, it is impossible to make a comparison between the bones obtained from the autopsy cadavers and the ancient bones obtained from the cemetery.

Güner et al. [1] conducted a study on the retention of $\mathrm{Zn}, \mathrm{Cu}, \mathrm{Cd}, \mathrm{Pb}$, and arsenic in human bones unearthed at the Central Anatolia and belonging to early bronze age. They used rib samples for analysis and compared their results with soil and water samples. They found that the major factor behind the accumulation depends not only on diagenesis but also on burial gifts. Although the place of this study is close to our excavation site, the time is completely different and our results are not similar to those of that study.

There are two limitations of this study. Lack of strontium, calcium, and barium assessment in the bones is the first limitation of this study, as these three elements are critical to determine the paleodiet of ancient people [14]. We could not examine $\mathrm{Sr}, \mathrm{Ca}$, and $\mathrm{Ba}$ levels, because the lamps for these elements were not available in our institution at the time of this study. The second limitation is the absence of control group for comparison of the results. We could not compare our results with those of contemporary bones.

In conclusion, the people of Camihöyük probably consumed high-protein diet and more vegetables than meat. The male population were exposed to heavy metals more than the females did. $\mathrm{Pb}$ exposure to this population likely occurred when they were still alive. Diagenesis may affect Fe, Mn, and $\mathrm{Cu}$ concentrations in the bones. Further studies with more skeletons and element analysis are needed to reveal the living conditions and dietary style of this population.

\section{References}

[1] C. Güner, V. Aliev, D. Atamtürk, I. Duyar, and F. Soylemezoglu, "Retention of $\mathrm{Zn}, \mathrm{Cu}, \mathrm{Cd}, \mathrm{Pb}$, and $\mathrm{As}$ on human bones unearthed at a Central Anatolian Early Bronze Age excavation site (Resuloğlu, Turkey)," Eurasian Journal of Anthropology, vol. 2, no. 1, pp. 27-39, 2011.

[2] L. L. Klepinger, "Nutritional assessment from bone," Annual Review of Anthropology, vol. 13, pp. 75-96, 1984.

[3] J. A. Ezzo, "Dietary change and variability at Grasshopper Pueblo, Arizona," Journal of Anthropological Archaeology, vol. 11, no. 3, pp. 219-289, 1992.

[4] L. L. Klepingera, "Magnesium ingestion and bone magnesium concentration in paleodietary reconstruction: cautionary evidence from an animal model," Journal of Archaeological Science, vol. 17, no. 5, pp. 513-517, 1990.

[5] J. F. Farnum, M. D. Glascock, M. K. Sandford, and S. Gerritsen, "Trace elements in ancient human bone and associated soil using NAA," Journal of Radioanalytical and Nuclear Chemistry, vol. 196, no. 2, pp. 267-274, 1995.

[6] A. Jurkiewicz, D. Wiechuła, R. Nowak, T. Gaździk, and K. Loska, "Metal content in femoral head spongious bone of people living in regions of different degrees of environmental pollution in Southern and Middle Poland," Ecotoxicology and Environmental Safety, vol. 59, no. 1, pp. 95-101, 2004.

[7] M. J. Martínez-García, J. M. Moreno, J. Moreno-Clavel et al., "Heavy metals in human bones in different historical epochs," Science of the Total Environment, vol. 348, no. 1-3, pp. 51-72, 2005. 
[8] M. M. Shafer, M. Siker, J. T. Overdier, P. C. Ramsl, M. TeschlerNicola, and P. M. Farrell, "Enhanced methods for assessment of the trace element composition of Iron Age bone," Science of the Total Environment, vol. 401, no. 1-3, pp. 144-161, 2008.

[9] J. B. Lambert, S. M. Vlasak, A. C. Thometz, and J. E. Buikstra, "A comparative study of the chemical analysis of ribs and femurs in woodland populations," American Journal of Physical Anthropology, vol. 59, no. 3, pp. 289-294, 1982.

[10] L. A. Beck, "Bivariate analysis of trace elements in bone," Journal of Human Evolution, vol. 14, no. 5, pp. 493-502, 1985.

[11] Y. C. Yoo, K. L. Sang, Y. Y. Ja et al., "Organ distribution of heavy metals in autopsy material from normal Korean," Journal of Health Science, vol. 48, no. 2, pp. 186-194, 2002.

[12] J. E. Buikstra and D. H. Ubelaker, Standards for Data Collection from Human Skeletal Remains, Arkansas Archaeological Survey Research Series, No 44, Arkansas Archaeological Survey Research, Fayetteville, Wash, USA, 1994.

[13] J. B. Lambert, S. Vlasak Simpson, C. B. Szpunar, and J. E. Buikstra, "Bone diagenesis and dietary analysis," Journal of Human Evolution, vol. 14, no. 5, pp. 477-482, 1985.

[14] M. T. Çırak, "The determination of nutrition of ancient Anatolian population with trace element analysis," Journal of World of Turks, vol. 2, no. 2, pp. 191-200, 2010.

[15] J. Velasco-Vázquez, M. Arnay-de-la-Rosa, E. González-Reimers, and O. Hernández-Torres, "Paleodietary analysis on the prehistoric population of El Hierro (Canary Islands)," Biological Trace Element Research, vol. 60, no. 3, pp. 235-241, 1997.

[16] J. B. Lambert, C. B. Szpunar, and J. E. Buikstra, "Chemical analysis of excavated human bone from middle and late Woodland sites," Archaeometry, vol. 21, pp. 115-129, 1979.

[17] J. A. Ezzo, C. S. Larsen, and J. H. Burton, "Elemental signatures of human diets from the Georgia bight," American Journal of Physical Anthropology, vol. 98, no. 4, pp. 471-481, 1995.

[18] J. E. Ericson, D. R. Smith, and A. R. Flegal, "Skeletal concentrations of lead, cadmium, zinc, and silver in ancient North American Pecos Indians," Environmental Health Perspectives, vol. 93, pp. 217-223, 1991.

[19] I. Baranowska, K. Czernicki, and R. Aleksandrowicz, "The analysis of lead, cadmium, zinc, copper and nickel content in human bones from the Upper Silesian industrial district," Science of the Total Environment, vol. 159, no. 2-3, pp. 155-162, 1995.

[20] I. A. Bergdahl, U. Strfmberg, L. Gerhardsson, A. Schqtz, D. A. Chettle, and S. Skerfving, "Concentraciones de plomo en los huesos tibial y calcáneo en relación con la historia de exposición ocupacional al plomo," Scandinavian Journal of Work, Environment \& Health, vol. 24, pp. 38-45, 1998.

[21] J. L. Kitman, The Secret History of Lead, The Nation, 2000.

[22] S. J. Rosenberg, Nickel and Its Alloys, Department of Commerce. National Bureau of Standards, Washington, DC, USA, 1968.

[23] G. F. Zimmer, "The use of meteroric iron by primitive man," The Journal of the Iron and Steel Institute, vol. 94, article 306, 1916.

[24] T. A. Rickart, "The use of meteoric iron," Journal of the Royal Anthropological Institute, vol. 71, article 55, 1941.

[25] R. J. Braidwood, J. E. Burke, and N. H. Nachtrieb, "Ancient syrian coppers and bronzes," Journal of Chemical Education, vol. 28, pp. 87-96, 1951.

[26] F. B. Howard-White, Nickel-An Historical Review, Van Nostrand, 1963.
[27] F. Miculescu, M. Miculescu, L. T. Ciocan et al., "Comparative studies regarding heavy elements concentration in human cortical bone," Digest Journal of Nanomaterials and Biostructures, vol. 6, no. 3, pp. 1117-1127, 2011.

[28] E. González-Reimers, J. Velasco-Vázquez, M. Arnay-de-laRosa, F. Santolaria-Fernández, and L. Galindo-Martín, "Paleonutritional analysis of the pre-Hispanic population from Fuerteventura (Canary Islands)," Science of the Total Environment, vol. 264, no. 3, pp. 215-220, 2001.

[29] L. T. Fairhall, R. C. Dunn, N. E. Sharpless, and E. A. Pritchard, "The toxicity of molybdenum," Public Health Bulletin, vol. 293, pp. 1-36, 1945.

[30] R. I. Gilbert, Trace element analyses of three Amerindian populations at Dickson Mounds [Ph.D. dissertation], University of Massachusetts, 1975.

[31] S. S. Jeng and L. T. Sun, "Effects of dietary zinc levels on zinc concentrations in tissues of common carp," Journal of Nutrition, vol. 111, no. 1, pp. 134-140, 1981.

[32] A. L. Rheingold, S. Hues, and M. N. Cohen, "Strontium and zinc content in bones as an indication of diet," Journrl of Chemical Education, vol. 60, no. 3, pp. 233-234, 1983.

[33] T. Li and B. L. Vallee, "The biochemical and nutritional roles of other trace elements," in Modern Nutrition in Health and Disease, R. S. Goodhart and M. E. Shils, Eds., Lea and Febiger, Philadelphia, Pa, USA, 6th edition, 1980.

[34] K. Guggenheim and D. Gaster, "The role of manganese, copper, and zinc in the physiology of bones and teeth," in Biological Mineralization, I. Zipkin, Ed., John Wiley \& Sons, New York, NY, USA, 1973.

[35] H. A. Schroeder, J. J. Balassa, and I. H. Tipton, "Essential trace metals in man: manganese. A study in homeostasis," Journal of Chronic Diseases, vol. 19, no. 5, pp. 545-571, 1966.

[36] H. Nie, D. R. Chettle, L. Q. Luo, and J. M. O’Meara, “In-vivo investigation of a new ${ }_{109} \mathrm{Cd}$ gammaray induced $\mathrm{K}-\mathrm{XRF}$ bone lead measurement system," Physics in Medicine and Biology, vol. 51, pp. 351-360, 2006.

[37] M. O. Yamada, T. Minami, M. Ichii et al., "An improved method for estimating original mineral contents in excavated bone using sulfur," Biological Trace Element Research, vol. 52, no. 2, pp. 155-161, 1996.

[38] M. J. Arnaud, "Update on the assessment of magnesium status," British Journal of Nutrition, vol. 99, supplement S3, pp. S24-S36, 2008.

[39] R. G. V. Hancock, M. D. Grynpas, and K. P. H. Pritzker, "The abuse of bone analyses for archaeological dietary studies," Archaeometry, vol. 31, pp. 169-179, 1989. 

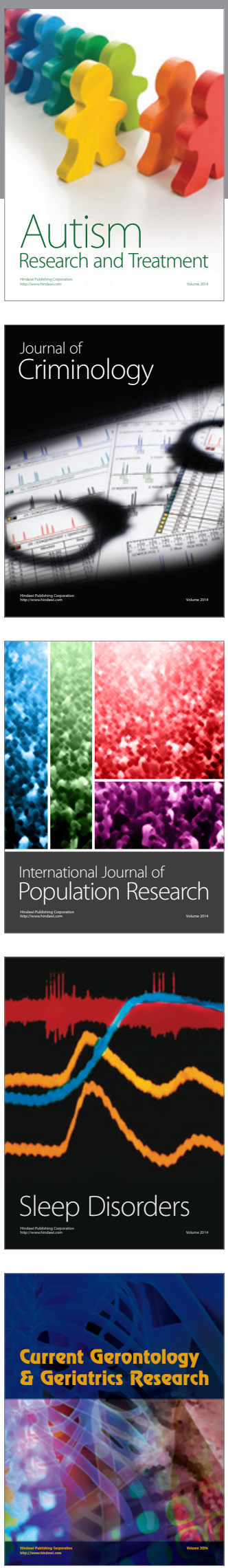
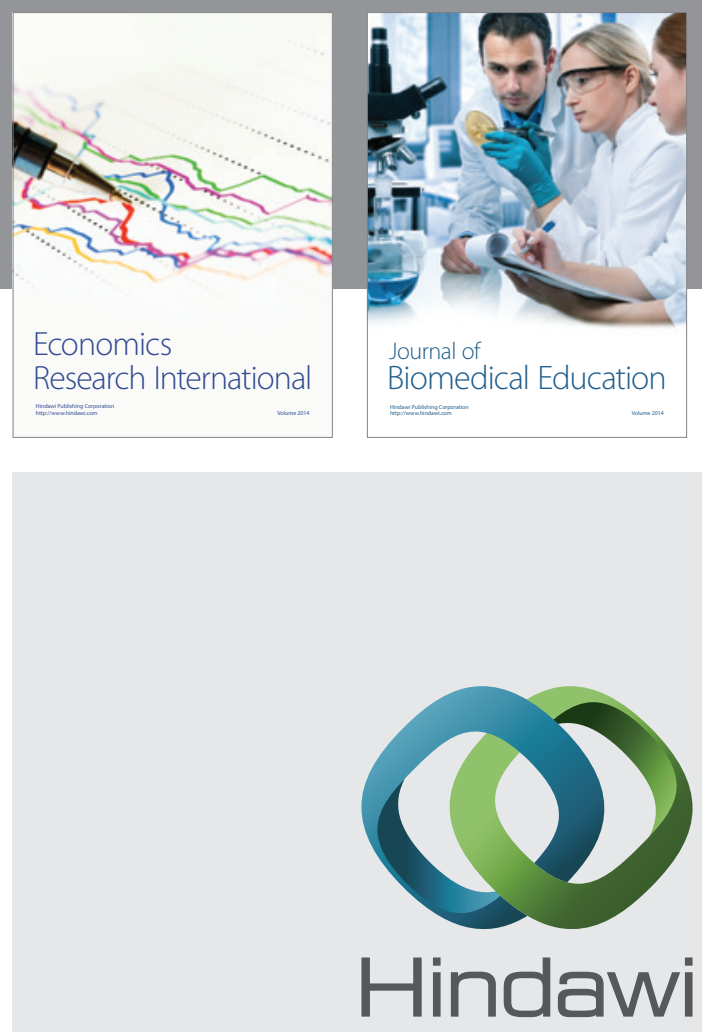

Submit your manuscripts at

http://www.hindawi.com
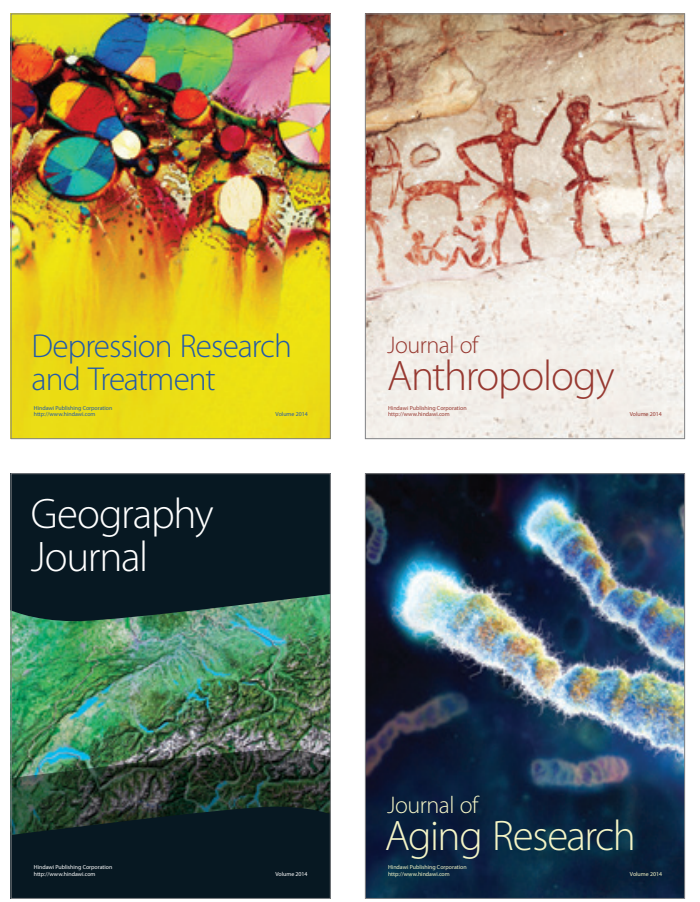
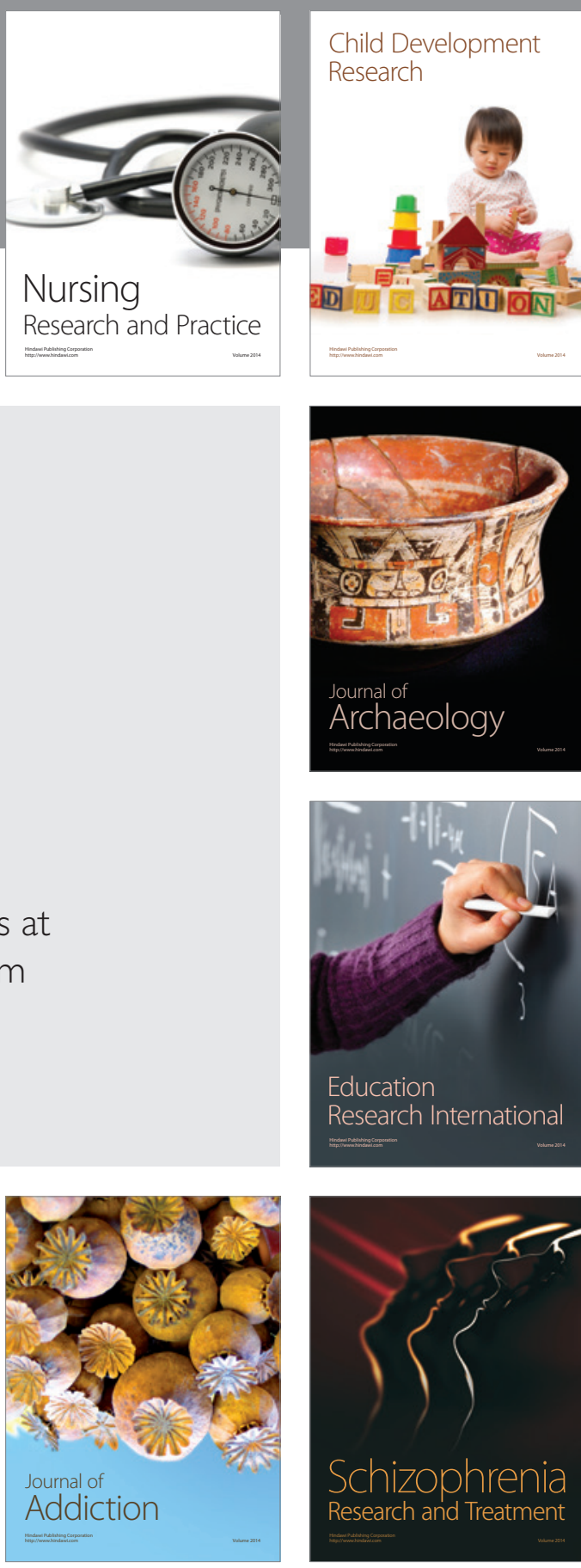

(D)
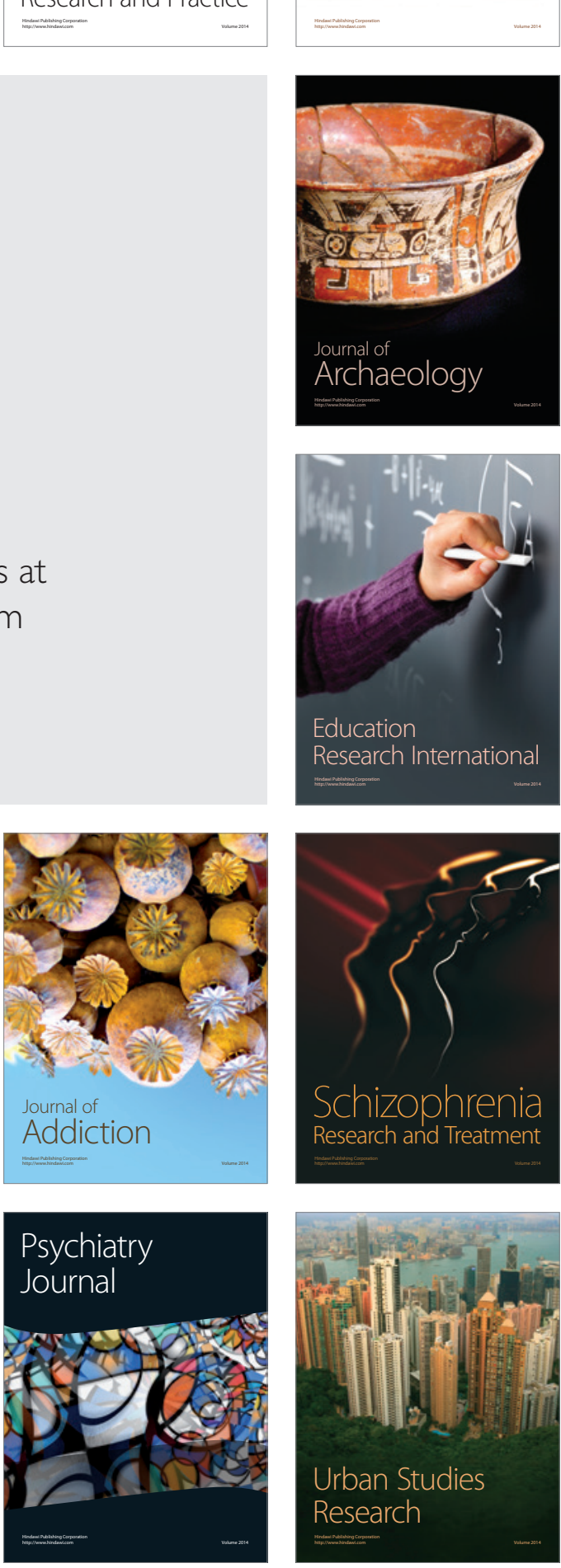